\title{
THE EFFECT OF APPLICATION OF WORK SAFETY AND HEALTH MANAGEMENT SYSTEM (K3) AND ORGANIZATIONAL CULTURE ON EMPLOYEE WORK SATISFACTION IN TK II HOSPITAL dr. SOEPRAOEN MALANG
}

\author{
Suripto $^{1}$, Byba Melda Suhita ${ }^{2}$ Indasah $^{3}$ \\ ${ }^{1}$ Magister of Public Health Program, Stikes Surya Mitra Husada Kediri, Indonesia \\ ${ }^{2,3}$ Lecturer of Magister of Public Health Program, Stikes Surya Mitra Husada Kediri, Indonesia \\ Corresponding author: Suripto (ripto4037@gmail.com)
}

\begin{abstract}
Occupational safety and health $(K 3)$ is an effort to create a safe and comfortable atmosphere to achieve the highest productivity. Factors which influence to achieve the purpose of these efforts, including the company's commitment; leadership policy regarding (K3); policies for the creation of a work environment in order to create K3, delegation of authority, implementation of training and education during the project; prevention of workplace accidents; tracing the main causes of work accidents; measure program performance (K3); and continuous documentation and records of work accidents. The research design used is quantitative research. The sampling technique used proportional sampling with a sample of 100 respondents. Data analysis techniques using multiple linear regression tests. The results show that there was a significant effect and the t test showed 6,665> t table (2,000), meaning that occupational safety and health had a significant effect on job satisfaction and there was a significant effect and the t test showed 6.802>t table $(2,000)$, meaning spatial planning significant effect on employee job satisfaction. Based on the explanation, it can be concluded that the better the K3 management system, organizational culture, K3 management system, the higher the level of Employee Job Satisfaction at the Hospital. II dr. Soepraoen; and the organizational culture (X2) has the highest dominant influence toward employee satisfaction.
\end{abstract}

Keywords: Job satisfaction, occupational safety and health (K3) management system, and organizational culture

Copyright (c) 2019 Stikes Surya Mitra Husada. All right reserved.

\section{INTRODUCTION}

Job satisfaction is one of the important indicators in getting optimal results in a company or agency. A person who is satisfied at work will demonstrate his ability to the maximum extent possible to complete the task given to him. By increasing job satisfaction, the work performance will increase. Job satisfaction can be formed by several factors both internal and external factors such as organizational cultural climate, work relations, communication patterns, OSH management, HR development programs etc. (Mathis dan Jackson, 2013). Therefore, an agency needs to know and control factors that can reduce or increase job satisfaction of its employees.

The application of work safety and health management system (k3) and organizational culture has an effect on employee satisfaction in hospitals at Tk II Hospital - dr. Soepraoen Malang. Mathis \& Jackson (2013: 107) explain that job satisfaction is a positive emotional state of evaluating one's work experience. Job dissatisfaction arises when these expectations are not met. Workload is needed to maintain motivation from employees and be more committed to an agency. This states that the company asks employees to maximize their performance in achieving institutional goals. 


\section{METHODS}

Research by using quantitative methods to determine the effect and relationship between independent variables (independent variables) on the dependent variable (dependent variable). To prove the correlation relationship and causal relationship, researchers used quantitative research methods causal research. Causal research aims to determine the relationship or involvement between these variables (Rangkuti, 2005).

The population in this study is permanent employees in Tk. II Hospital - dr. Soepraoen. Malang. The population in this study were 300 people (58 medical staff, 142 non-medical employees, 66 nonparamedic employees, 34 paramedic employees). While the sample in this study is as many as 100 employees.

Data collection techniques in this study are two methods. The first method is survey method. The survey method is collecting data and information which is done by visiting the object of the research in question, so that the data and information obtained can be believed to be true in which the respondents observed are not too large (Indriantoro, 2002: 152). In the survey method researchers used a questionnaire to obtain data directly from the object under study. Next is the documentation method. The documentation method is a data collection in which the written objects such as books, magazines, documents, regulations, and so on was investigate (Arikunto, 2002: 158). This method is used to obtain data on the number of patients at Tk. II Hospital - dr. Soepraoen.

\section{RESULTS}

\section{Table 1 T-test Result}

\begin{tabular}{clcccc}
\hline No & \multicolumn{1}{c}{ Variable } & t-count & t-table (standard) & Sig. & Explanation \\
\hline 1 & $\begin{array}{l}\text { Work health and } \\
\text { safety (K3) }\end{array}$ & 6.665 & 2.000 & 0.000 & Significant \\
\hline 2 & $\begin{array}{l}\text { Organizational } \\
\text { culture }\end{array}$ & 6.802 & 2.000 & 0.000 & Significant \\
\hline
\end{tabular}

Source: Data processed in 2018

The t-test (partial) statistical test shows the effect of occupational safety and health (K3) and organizational culture on employee job satisfaction $(\mathrm{Y})$ is partially influential. Based on the table above, it can be described as follows:

1) Work Safety Variable (X1) has a significance value (Sig.) 0,000 in the Coefficientsa table with a value of $\alpha$ (significance degree) 0.05 which means $0,000<0.05$ or there is a significant effect and $\mathrm{t}$ test shows $6,665>\mathrm{t}$ table $(2,000)$. This means that occupational safety and health has a significant effect on job satisfaction.

2) The organizational culture variable (X2) has a significance value (Sig.) 0,000 in the Coefficientsa table with a value of $\alpha$ (significance degree) 0.05 which means $0,000<0.05$ or there is a significant effect and the $t$ test shows 6.802> t table $(2,000)$. This means that spatial planning has a significant effect on employee job satisfaction.

Table 2 F-test Result

\begin{tabular}{cccccc}
\hline No & \multicolumn{1}{c}{ Variabel } & f-count & f-table & Sig. & Explanation \\
\hline 1 & $\begin{array}{l}\text { Work health and safety (K3) and } \\
\text { Organizational culture }\end{array}$ & 638.759 & 2.74 & 0.000 & Significant \\
\hline
\end{tabular}

Source: Data processed in 2018

Based on the table above, the results obtained from the $\mathrm{F}$ statistic test are obtained $\mathrm{f}$ statistic value of 638,759 and a significance value of 0,000 where this result is greater than $F$ table (2.74) at $n$ 
of 100 so Ho is rejected which can be concluded that occupational safety and health ( K3) and organizational culture simultaneously have a significant effect on employee job satisfaction.

Table 3 Determination Coefficient $\mathbf{R}^{2}$

\begin{tabular}{|c|c|c|c|c|c|}
\hline No & Variable & $\begin{array}{c}\mathrm{R} \\
\text { (relatonship) }\end{array}$ & $\begin{array}{l}\text { R Square } \\
\text { (influenc } \\
\text { e) }\end{array}$ & $\begin{array}{c}\text { Adjusted R Square } \\
\text { (influence without } \\
\text { constants and } \\
\text { confounding variables) }\end{array}$ & $\begin{array}{l}\text { Std. Error of the } \\
\text { Estimate } \\
\text { (disturbing } \\
\text { variable) } \\
\end{array}$ \\
\hline 1 & $\begin{array}{l}\text { Work health and } \\
\text { safety (K3) and } \\
\text { Organizational } \\
\text { culture }\end{array}$ & 0.964 & 0.929 & 0.928 & 0.15075 \\
\hline
\end{tabular}

Source: Data processed in 2018

Based on table 4.22 above, the R2 (R Square) number is 0.929 or (92.9\%). This shows that the percentage contribution of the independent variables of occupational safety and health (K3) and organizational culture to the dependent variable of employee job satisfaction is $92.9 \%$. Or variations in the independent variables used by employee safety and organizational culture are able to explain 92.9\% variation in the dependent variable (employee job satisfaction). While the remaining $7.1 \%$ is influenced or explained by other variables not included in this research model.

The Standard Error of the Estimate is a measure of the number of errors in the regression model in predicting the value of Y. From the regression results the value is 0.15075 , this means that the number of errors in predicting employee performance satisfaction is 0.15075 . As a guideline if the Standard error of the estimate is less than the standard Y deviation, the regression model is better at predicting the $\mathrm{Y}$ value.

Table 4 Summary of Regression Analysis Results

\begin{tabular}{llll}
\hline No & Variable & Beta & Explanation \\
\hline 1 & Work health and safety (K3) & 0.446 & \\
\hline 2 & Organizational culture & 0.466 & \\
\hline
\end{tabular}

Source: Data processed in 2018

Based on the table above, it can be seen that all independent variables are partially significant towards Y. Variables of organizational culture variables (X2) have the same regression coefficients. This shows that $\mathrm{Y}$ (employee job satisfaction) is influenced by organizational culture (X2) with equal parts.

\section{DISCUSSION}

\section{A. Effects of Application of Work Safety and Health Management System (K3) on Employee Job Satisfaction During At TK II Hospital Dr. Soepraoen}

Work safety and health according to Rivai and Jauvani (2013: 792) refer to the physiologicalphysical and psychological conditions of labor caused by the work environment provided by the company. According to Mangkunegara (2014: 160) occupational safety and health is a safe condition or survived suffering, damage or loss at work.

Based on the results of the study, it is known that the occupational safety and health management system (K3) has a positive and significant effect on employee job satisfaction at the TK Hospital. II - dr. Soepraoen. This is evidenced by the Occupational Safety variable (X1) having a significance value (Sig.) 0,000 in the Coefficientsa table with a value of $\alpha$ (significance degree) 0.05 
which means $0.003<0.05$ or there is a significant effect and $t$ test shows $6.665>t$ table $(2,000)$. This means that occupational safety and health has a significant effect on job satisfaction.

Basically, job satisfaction is an individual thing, where every individual wants a guarantee of safety while working. The more safety aspects that match the desires of the individual, the higher the level of satisfaction that arises in the individual. Like the theory put forward by Mangkunegara (2013: 161) that the need for protection from threats, hazards, conflicts and the environment is needed to create individual satisfaction.

The results of this study support the results of previous studies conducted by Fajri, Utami \& Prasetya (2017) where work safety has a significant effect on employee job satisfaction. A wellimplemented work safety program can directly improve employee job satisfaction. Karyawana is satisfied with security in every optimal work activity.

\section{B. The Effect of Organizational Culture Application toward Employees' Job Satisfaction while Working at Tk II Hospital - dr. Soepraoen}

Organizational culture is meanings system embraced by members distinguishing their organization to others. Culture becomes an advantage of a company if the culture can support organizational goals and make the organization adapt the increasingly rapid development of the times. Organizations that do not have a strong culture tend not to have self-identity and adopt other corporate cultures that may not be in accordance with the organization they have. Specifically culture in the organization will be determined by the conditions of team work, leaders and characteristic of organization as well as the applicable administration process. The diversity of cultures that exist within the organization. Then raises diversity in its application. But it is this difference that ultimately fills and complements each other. Covering weaknesses and strengthening each other among elements in the organization.

According to Steven Set Xaverius Tumbelaka, Taher Alhabsji and Umar Nimron (2016), the stronger the organizational culture in the company, the higher the employees' job satisfaction increase. Employees feel the company always emphasize its employees to always be careful and pay attention in detail when doing their work. Since the company is engaged in production, the most work processes in the company are directly related to production equipment that requires precision in operation. The inaccurate or not concerned in detail endanger the employees. The disoperation of production equipment can also result in a production process that is hampered or stopped, this makes the employee feel the work he does has considerable responsibility in the course of the production process in the company which ultimately fosters a sense of satisfaction on the work they have.

\section{Effect of the Implementation of Work Safety and Health Management System (K3) and Organizational Culture on Employee Satisfaction at Tk II Hospital - dr. Soepraoen Malang}

Based on data analysis that has been carried out in the study, it can be seen that together, the two variables X, namely the Implementation of Work Safety and Health Management System (K3) and organizational culture have a significant positive effect on Employee satisfaction at TK II Hospital - dr.Soepraoen Malang . This means that the better and higher the implementation of the Work Safety and Health Management System (K3) and organizational culture owned by the hospital will be followed by the higher employee satisfaction at the hospital. Conversely the lower the level of Implementation of Work Safety and Health Management System (K3) and organizational culture owned by the hospital, it will be followed by the lower level of employee satisfaction.

Based on the results of the $F$ statistic test, the calculated statistic $f$ is 638,759 and the significance value of 0,000 where this result is greater than $F$ table (2.74) at $n$ of 100 so that Ho is rejected which can be concluded that work safety and health (K3) and organizational culture simultaneously has a significant effect on employee job satisfaction.

From the results of observations and questionnaires that have been filled by respondents, Tk. II Hospital - dr. Soepraoen has fulfilled several indicators or parameters set by the Government as evidenced by the attached data. Based on the explanation described above, it can be concluded that employee job satisfaction can be influenced by the high and low occupational safety and health and organizational culture. 
D. Dominant Influence of Application of Work Safety and Health Management System (K3) and Organizational Culture to Employee Satisfaction at Tk II Hospital - dr. Soepraoen Malang

In determining the independent variable that has the most influence on $\mathrm{Y}$, it can be done by comparing the regression coefficient $(\beta)$ between the variables with one another. The most dominant variable affecting $\mathrm{Y}$ is the variable that has the greatest regression coefficient. Based on the results of research on the domain test shows that the variable X2 (organizational culture) has the highest dominant influence on the employee satisfaction variable with a beta value of 0.466 compared with the K3 variable (0.446). But not only that, Occupational Health and Safety can also affect employee satisfaction as well as creating a better work culture if Occupational Health and Safety is done well by every employee.

From the description above, it can be seen things that need to be considered and considered in carrying out performance so that an atmosphere of work that is safe, comfortable and achieves an objective is achieved, namely the highest productivity.

\section{CONCLUSION}

The results of the study on data analysis:

1. Work Safety and Health Variables show an overall average value of 4.08 with a percentage of $36 \%$ and a high category.

2. The organizational culture variable has an overall average value of 4.07 with a percentage of $61 \%$ with a high category.

3. Variable job satisfaction has an overall average value of 4.00 in the percentage of $68 \%$ with a high category.

4. Based on the results of the $t$ test, there is a significant effect and the $t$ test shows 6.665> $t$ table $(2,000)$ means that occupational safety and health has a significant effect on job satisfaction.

5. Based on the results of the $t$ test, there is a significant effect and the $t$ test shows 6.802> $t$ table $(2,000)$ meaning that spatial planning has a significant effect on employee job satisfaction.

6. Based on the F statistical test, the calculated $\mathrm{f}$ statistic is 638,759 and the significance value is 0,000 where this result is greater than F table (2.74) at $\mathrm{n}$ of 100 so that Ho is rejected which can be concluded that occupational safety and health (K3) and organizational culture simultaneously has a significant effect on employee job satisfaction.

Based on the obtained number R2 (R Square) of 0.929 or (92.9\%). This shows that the percentage contribution of the independent variables of occupational safety and health (K3) and organizational culture to the dependent variable of employee job satisfaction is $92.9 \%$.

\section{SUGGESTION}

1. It is expected that the human resource management at Tk II Hospital - dr. Soepraoen will pay attention to and improve the application of the OSH system and organizational culture so that employee job satisfaction can further improve.

2. It is expected that the next researcher can examine other factors that can affect employee job satisfaction, such as compensation, facilities, and so forth.

3. It is hoped that for Tk II Hospital - dr. Soepraoen employees who will be respondents in this study, so that satisfaction can be obtained by Tk II Hospital - dr. Soepraoen employees, then the management of Tk II Hospital - dr. Soepraoen should have more efforts to improve employee performance by creating an organizational culture and a better Work Safety and Health Management System (K3). 


\section{REFERENCES}

Alfin, R., Alhabsji, T., Nimran, U., \& Suharyono. (2016). Effect of service quality and product quality to corporate image, customer satisfaction and customer trust. University of Brawijaya.

Arikunto, S. (2002). Metodologi Penelitian. Penerbit PT. Rineka Cipta. Jakarta.

Indriantoro, (2002), Metodologi Penelitian Bisnis, Cetakan Kedua, Yogyakara; Penerbit BPEE UGM.

Mangkunegara, \& Prabu, A. (2014). Manajemen Sumber Daya Manusia Perusahaan. Bandung: PT. Remaja Rosda Karya.

Mathis, Robert, L., \& Jackson, J., H. (2013). Human Resource Management, terjemahan, Edisi Kesepuluh, Jakarta, Salemba Empat.

Rangkuti, \& Freddy. (2005). Business Plan Teknik Membuat Perencanaan Bisnis \& Analisis Kasus. PT. Sun. Jakarta. 